\title{
Self-harm and suicidal acts: a suitable case for treatment of impulsivity-driven behaviour with repetitive transcranial magnetic stimulation (rTMS) - ADDENDUM
}

Derek K. Tracy, Sukhwinder S. Shergill, Anthony S. David, Peter Fonagy, Rashid Zaman, Jonathan Downar, Emma Eliott and Kamaldeep Bhui

\section{Copyright and usage}

(C) The Royal College of Psychiatrists 2019. This is an Open Access article, distributed under the terms of the creative Commons Attribution-NonCommercial-NoDerivatives licence (http://creativecommons.org/licenses/by-nc-nd/4.0/), which permits non-commercial re-use, distribution, and reproduction in any medium, provided the original work is unaltered and is properly cited. The written permission of Cambridge University Press must be obtained for commercial re-use or in order to create a derivative work.

https://doi.org/10.1192/bjpo.bp.115.000315, Published online by the Royal College of Psychiatrists, 2nd January 2018.

There was an oversight regarding the acknowledgement of funding from the European Research Council, which was a contractual obligation for the funding. Professor Sukhwinder S. Shergill was funded by an ERC Consolidator Award.
Derek K. Tracy; Sukhwinder S. Shergill; Anthony S. David; Peter Fonagy;

Rashid Zaman; Jonathan Downar; Emma Eliott; Kamaldeep Bhui

\section{Reference}

Tracy DK, Shergill SS, David AS, Fonagy P, Zaman R, Downar J, Eliott E, et al. Selfharm and suicidal acts: a suitable case for treatment of impulsivity-driven behaviour with repetitive transcranial magnetic stimulation (rTMS). BJPsych Open 2015; 1: 87-91. 